\title{
Review of the Impact of Cultural Imperialism in the Context of Globalization to the Film Industry
}

\author{
Xinyi Chen ${ }^{1, a, \uparrow}$ and Siwen Shen ${ }^{2, b, \dagger}$ \\ ${ }^{1}$ Department of Culture, Media and Creative Industry, King's College, London, WC2R 2LS, The United Kingdom; \\ ${ }^{2}$ School of Business, Jiangnan University, Wuxi, Jiangsu 214122, The People's Republic of China.

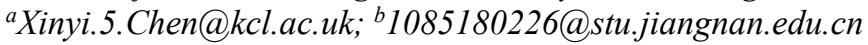 \\ These authors contributed equally.
}

\begin{abstract}
Since the 1970s, though, cultural imperialism has been put forward and sparked a series of discussions, yet under the background of globalization, cultural imperialism has exerted more and more significant influence on the film industry of various countries. The impact of Western media flow on the film industry of other countries has long been hard to ignored. As the homogenization of the film industry has become a global problem, this paper further studies the role of cultural imperialism in the global film industry by discussing the origin of cultural imperialism and its development in the context of globalization. Both positive and negative influence of cultural imperialism on the film industry will be addressed. The article will take the response of the film industry in non-Western countries to cultural imperialism as the starting point to explore the possibility of the heterogeneity of the film industry under the influence of cultural imperialism.
\end{abstract}

\section{Keywords: Cultural imperialism, Globalization, Homogenization, Heterogenization, Film industry}

\section{INTRODUCTION}

Globalization has long been one of the inevitable mainstream trends in the world and has penetrated into every aspect of people's daily life. Globalization is a further process in the later stage of internationalization development. As Mirrlees stated, this trend of globalization can be seen as the astonishing expansion of transnational capitalism and its control over the global communications infrastructure, and based on the state to achieve its marketing, operation and opinion control purposes [1]. It is this Western control that makes the concept of cultural imperialism clear. Since many previous scholars have laid the groundwork for the topic from the perspective of governmentality, colonialism, and power [2]. Edward Said was influenced by these studies and combined these ideas to unify his thoughts about cultural imperialism in his book, Cultural and Imperialism (1993). And his work successfully brought the concept to the public view. Said stated in his book that the Western's misunderstood the role that imperial conquest played in shaping their cultures -- that they still viewed their own culture as superior to other cultures. With the development of the modern film industry, the transnational cooperation exposes the industry to the possible influence of cultural imperialism. As Tomline said, the film industry is suffering from "media imperialism" [3]. According to Narine, the cultural imperialism of the modern film industry mainly comes from the influence of the American film industry, and the primary goal of American foreign policy is to spread Western style "democracy" [4]. Scholars of cultural imperialism often claim that non-Western cultures, especially those from developing countries, often lose their traditional values and cultural identities as long as they are exposed to Western media [5]. But at the same time, Salwen in his article Critical Studies of Mass Communication (1991), claims that comprehensive consideration and integration of the influence of cultural imperialism is essential to understand the film industry in the international context. In the context of the rapid spread of global culture, he points out two possible outcomes of cultural imperialism. On the one hand, cultural imperialism causes cultural destruction to developing countries. Western media can distort the image of other cultures and in some cases trigger the loss of indigenous cultures in developing countries, and therefore lead to the homogeneity. On the other hand, governments or people of developing countries may actively resist the invasion of foreign cultures and 
maintain the unique cultural characteristics of local film industry [6]. Although the outward manifestations of Western culture may be adopted, basic cultural values and behaviors remain unchanged.

It is worth mentioning that before the United States became the dominant figure in cultural imperialism, the Soviet Union had similar cultural invasions of other countries. At that time, globalization had not yet become mainstream, and the concept of cultural imperialism had not yet been defined. Although this kind of cultural imperialism -- or cultural colonialism as Andrada FătuTutoveanu suggested -- is more based on ideology rather than the trend of globalization, which might be a little bit different from the American cultural imperialism, academic research on it can still provide us with valuable insights [7]. These years, most studies of the impact of cultural imperialism on the film industry in the context of globalization have also focused on certain cultural phenomena, as with those studies of Soviet cultural colonialism. For example, scholars from Nigeria have conducted research on the impact of cultural imperialism on the Nigerian film industry in 2008, when the discussion about the correlations among cultural imperialism, globalization, and the film industry had not yet received as much mainstream academic attention as today. The paper mentioned that foreign films from countries such as the United States were quite popular in Nigeria than those locally produced films as they could not meet the audience's satisfaction of entertainment [8]. In the last twenty years, there have been many similar studies, mostly focusing on case studies of the impact of cultural imperialism on the film industry in Third World countries like Nigeria. The cultural phenomena that can be investigated are naturally innumerable. In addition to Nigeria's Nollywood, India's Bollywood, the film industries of China, Japan, South Korea and other Asian countries or the Latin American film industry have also been the subjects of much scholarly discussion. Most of these countries have the history of being colonized or invaded by the West, which remains one of the bases of cultural imperialism, as the Indian scholar Babli Sinha put it. According to Babli, the influence of cultural imperialism on the Indian film industry can even be traced back to the 1930s, when the "empire films" were among the most popular [9]. However, due to the formation of the globalization system, the colonialist aspects of cultural imperialism have been gradually receding, and cultural imperialism today manifests itself more in the form of intercultural encounter [10]. Obviously, the study of cultural imperialism in the film industry has been affected to a certain extent. Modern cultural imperialism not only represents the homogenization and Americanization of culture, but also promotes the cultural pluralism from another aspect, thus promoting the heterogeneity of different cultures and finally realizing the glocalization. The same applies to the film industry, of course.
Considering this newly emerging condition of the contemporary globalization system, the cultural imperialism dominated by the West, especially the United States, urgently needs to be re-evaluated. Therefore, in this review, research on the impact of cultural imperialism on the film industry in the context of globalization will be systematically summarized. In view of the complexity of the current academic debate on the topic, diversified opinions on the subject would get collated. The conceptions involved will also be explained in detail, including the concepts of cultural imperialism, globalization, and the definition of the film industry.

\section{THE ORIGIN AND BACKGROUND OF CULTURAL IMPERIALISM}

The concept of cultural imperialism began to be intensively discussed by scholars from the 1970s. Generally speaking, cultural imperialism means that foreign cultures invade the local culture and intend to place it above the local culture. As Herlihy puts it, cultural imperialism is a process intended to transform "the cultural symbols of an invading group from 'foreign' to 'natural' domestic" [11]. Scholars have expounded the characteristics of cultural imperialism on the basis that cultural hardware and software and other cultural forms attempt to occupy the culture of another country, on the basis that the common values of a national or regional cultural system invade the native culture. And this process has largely undermined the values of the local culture [12]. Nelwan and Ezema both pointed out that cultural imperialism is essentially an imbalance, which affects the way of cultural communication and leads to new cultural dependence, especially in the third world countries [13].

Although the conceptual term of cultural imperialism was only explicitly put forward around the 1970s, the phenomenon has a very long history. From a historical point of view, the existence of cultural imperialism is basically related to military intervention and territorial conquest. For example, with the expansion and rise of the British Empire, there were colonial areas in various regions, such as India and Hong Kong. Although these areas are no longer British colonies, the influence of British culture still exists in these areas -- for example, the use of the English language in Hong Kong. More than a century of British rule has consolidated the importance of English as a practical lingua franca in Hong Kong [14]. At the same time, English is vital to international trade and business and to Hong Kong's economic and social well-being. The United Kingdom also maintained a period of relative stability in the territory once affected by the war through a unified legal system, technological development, and other infrastructure building. However, this stability was built on the fact that the different cultural populations that Britain occupied were forced to accept British culture [15]. 
And the impact of globalization on the development of cultural imperialism has to be mentioned. Globalization has long been one of the inevitable mainstream trends in the world and has penetrated into every aspect of people's daily life. Globalization is a hybrid concept that plays an essential role in nowadays society. The theory of globalization began to rise in the critical period after the cold war. Its development has included the growth of international trade, the global movement of population, the increase in the number of international laws and forums, economic liberalism, as well as the rise of the media and the Internet and global digital communication networks [16]. The meaning of globalization has been evolving, but in general, it is a broad network of economic, cultural, social, and political connections and processes that span national boundaries. In this context, cultural imperialism has also been affected by some unique influences brought about by the era of globalization. It is worth paying attention to what these influences are and how they will be reflected in different aspects.

Cultural imperialism has developed more rapidly under the background of globalization. Ezema goes on to point out the catalytic role globalization plays in spreading cultural empires [13]. Modern globalization is actually driven by digital information technology, and from a fundamental point of view, digital information technology is actually the carrier of cultural communication. In the globalized information environment, the propagation speed of culture from one country or region to another country or region increases rapidly. Therefore, the more developed countries and regions with digital information technology, their cultural output speed is also very rapid. Globalization emphasizes and promotes liberalization and privatization, two characteristics that create more opportunities for many large transnational corporations with economic capital from developed countries or regions [13]. This overwhelming cultural output has led these countries to believe that cultural imperialism under globalization has removed cultural barriers and, at the same time eliminated the negative and feudal aspects of the culture of many developing countries. Although most developing countries still believe that such culture is imposed, the difference between positive culture and negative culture is only defined by the developed countries in the West, and globalization also lays the foundation for the development of cultural imperialism from these two characteristics [17].

\section{MODERN CULTURAL IMPERIALISM}

\subsection{Evolution and Transmutation}

Nearly sixty years have passed since the concept of cultural imperialism was first applied to the realm of the media by scholars. In 1975, Herbert Schiller elaborated on the cultural imperialism theory and described it as the dominant influence of the culture of Western countries over the culture of the weaker ones [18]. Nowadays, as the international situation changes, cultural imperialism is not static as well. With colonialism gradually fading and the trend of globalization and multi-polarization becoming mainstream, cultural imperialism has naturally transmuted into a whole new form. Since the post-World War II era, the U.S. government has been regularly active in establishing a global media market in order to seize its control over the international cultural industry. With the momentum of globalization, America has managed to form a dominant flow of culture with absolute supremacy. This is quite different from the ideologically driven colonial cultural imperialism of the Soviet Union and Britain in the past, which is no longer the direct subproduct of imperialism and colonialism, but rather subtle cultural assimilation that shakes the essence of other cultures from their very core [19]. Some scholars also argue that although colonialism has left us, the "colonial mentality" still exists. Thus, some countries that have been colonized retain an unrealistic illusion about their colonizers, and this tendency may even be reinforced after a few generations. In other words, the cultural imperialism of the colonial period is continuing with its effects, resulting in a symptomatic addiction to the dominant culture in areas of the weaker culture. Identical to decolonial cultural imperialism, such cultural imperialism no longer is imposed with force, but instead exerts its influence subconsciously [8].

The first transmutation of modern cultural imperialism is its transfer to the centre of the media industry. In the context of globalization, the mobility of various cultures has been enhanced. It is through the rapid development of the media under the support of globalization, especially the mainstream and mass transnational media, cultural imperialism is able to be prominent and significant in the global dissemination. Although cultural imperialism is a legacy of colonialism during the war, its emphasis has shifted in the context of today's globalization. Modern cultural imperialism is more concerned with the assimilation problems faced by media products such as literature, film, television, online games and music [20]. As McPhail points out, most of the world's major media companies are controlled by the same advanced core countries, which also guide the direction of global media production [12]. Schiller also said that the media around the world is actually controlled by Western countries, and this control has a great impact on the culture of third world countries. Cultural imperialism from the West imposes Western values on the third world countries through the media and their associated products, thus even destroying their native cultures. At the same time, the audience will also respond to the culture in the media, because there is no other way to compare with their own lives, and often the Western media's description is not so accurate [21]. Cultural 
imperialism has always played an indispensable role in global media communication. Based on this, Fejes proposed a dependency model, which means that the development of developing countries at all levels relies heavily on the so-called core countries [22]. Although people live in an era of globalization, the flow of culture is mostly one-way. Media products from the core Western world, such as TV and films, can be very popular in developing countries, but few media products from developing countries can flow in developed countries [24].

More precisely, the current trend towards cultural imperialism means "media imperialism". Boyd-Barret puts forward that media imperialism is closely related to cultural imperialism on at least three levels. First, the process of cultural imperialism is carried out, transformed or resisted to varying degrees through the media. Second, the media itself can be seen as a product of the maintenance and shaping of imperialism. The phenomenon of the media only producing and disseminating mainstream news in most cases is a case in point. Finally, the behaviour generated by the media can also be seen as driven by cultural imperialism. Because the active participation of commerce, economy, and politics in a specific country also profoundly influences culture imperialism. This effect is likely to be reinforced by various international media or news reports [23].

The second transmutation of cultural imperialism in modern times is more driven by Western culture represented by the United States. Many scholars claim that under the current background of globalization, cultural imperialism is often exported to other countries with the United States as the core [24]. According to Narine, "globalization" is promoting the homogenization of the global economy, politics and culture, and the cultural imperialism of spreading Western-style "democracy" is the primary goal of American foreign policy [4]. Stapell offers two different explanations for the role of the United States in cultural imperialism in the context of globalization. On the one hand, under the dominance of the United States, cultural imperialism actually created homogenization and consistency based on American culture [25]. Part of the argument is that American power in cultural imperialism is irresistible enough to lead to homogenization on a global scale. At the same time, some scholars have described that American cultural products have been screened and eliminated to some extent. When they arrive at other countries or regions, they have been adjusted to some extent. After combining with the local culture, the local culture is even strengthened [24]. Stapell goes on to argue that another explanation focuses on the aims and motives of the United States in cultural imperialism [25]. On the one hand, it discusses that the US-led cultural imperialism is helping other countries to realize the process of modernization. The purpose of American cultural imperialism is not to homogenize the culture, but to realize the free and democratic market economy and consumer culture on a global scale [26]. Different viewpoints hold that the motive of us-led cultural imperialism is to strengthen its own political and economic hegemony in other countries and lay a foundation for all-around imperialism in the future through cultural infiltration [27].

\subsection{A perspective from film industry}

The film industry is a global medium. The reach of a film is so vast that it can deliver the same content to a large audience. As Maisuwong says, the film industry can play a leading role in the entire global media industry [28]. The audience accepts the information contained in the film actively or passively. The interpretation of the film by the active audience will be different due to the moving perception or the influence of the external environment. And the passive audience is the group that is very easy to be disturbed by the foreign information conveyed by the film, which is also the breakthrough point for cultural imperialism to invade the local culture [29]. As a superpower country, the United States' efforts to promote American culture in the global society may affect the native culture of other countries. American movies are not only seen in the United States, but also have a large audience around the world [28].

As mentioned above, imperialism under the influence of globalization is not limited to politics, economy, business, and other aspects. A similar trend has also been seen in the field of culture. According to Mulligan, the international consumption of American media transmits a normative set of standards that reflect key aspects of American cultural identity [30]. Through media such as film, television and music, the rest of the world sees American values and ways of life and integrates and even caters to those values at a local or regional level [30]. As a subdivision of cultural imperialism, media imperialism is particularly prominent in the film industry. As Tomline puts it, the film industry is also suffering from "media imperialism" [3]. Scholars of cultural imperialism often claim that non-Western cultures, especially those from developing countries, often lose their traditional values and cultural identities as long as they are exposed to Western media $[3,8]$. The dominant position of the American film industry in the world reflects one of the main criticisms of cultural globalization, namely the potential homogenization effect of global culture, which threatens the uniqueness of national culture [31]. Looking at global film distribution, it is not difficult to find that American Hollywood has an almost overriding monopoly on the whole industry globally. In fact, this situation began in the mid-to-late twentieth century and has expanded as globalization has intensified. Hollywood in the United States is the mindset of filmmakers and audiences around the world. While there are films from around the world that export contra-flow to the United 
States, and thus influence American filmmakers, their impact pales in comparison to what Hollywood produces in other parts of the world. Rodman's summary said films from other countries are often clever remakes of Hollywood movies, rewritten to suit local culture [32]. However, these rewrites are often superficial, and their underlying local cultural values are not reflected. What this kind of film shows is still the culture centred on American values.

From a purely commercial point of view, Hollywood accounts for the lion's share of the profits from global film distribution [33]. This specific lack of local culture also led to the film gradually losing artistic value characteristics. The traditional value of film as an art form should depend on the concept of authenticity and creativity, which can be regarded as the importance of originality. However, in today's cultural environment, mechanical reproduction under American cultural imperialism destroys the real environment of artworks. The cultural industry under cultural imperialism takes the way of separating the copied objects from the field [34]. In other words, under the monopoly of American capitalism, the production and operation of the cultural industry are strictly restricted. This monopoly creates a deception for the masses. Cultural imperialism tries to convey the idea of a free market to the masses, which means that people are free to make their own choices according to their preferences. However, every film, magazine, and pop song are the same, and there is no choice. They are "replicas of meaningless cliches" [35]. The vast majority of American Hollywood films are easy to be understood by the audience, so the use of film exhibition soft power is one of the most cost-effective ways to gain recognition from other countries [36]. The promotion of American culture through films means that the United States aims to spread its own values through films, so as to achieve the purpose of leading the world in culture. The idea of Americanism is becoming more widely known around the world, and the export of American culture is accelerating. By exporting American culture in film, it becomes a means of cultural imperialism and a new political strategy in world politics [28].

\subsection{Responses from Developing Countries}

The contemporary world, under the influence of globalization, has acquired more compressive time and space. Social relations are broader, more frequent, more direct and more convenient than ever before. In the postindustrial phase of capitalism, the mobility of all relevant people, capital, goods, information and images has increased, and communication and transportation technologies have developed faster and more widely, as has access to them. While increasing and facilitating a range of cross-cultural contacts, globalization simultaneously enabled a type of global industrialization.
This is no doubt positive news for the film industry [37]. Glocalization of the film industry means that in the context of globalization, the film industry is not completely assimilated by Western cultural imperialism but continues to integrate the local culture into the film, so as to create films with local cultural characteristics to achieve heterogeneity. As Hasan and Nika discussed, the formation of the Indian Bollywood films could be considered one of the successful examples to show how the film industry could merge both local cultural characteristics and Western cultural imperialism. Bollywood may have a Hollywood platform in terms of stories, artists and foreign locations, but it still has Indian cultural characteristics, such as the incorporation of song and dance elements in films and the reflection of the values of Indian family culture in films [38].

As cultural imperialism evolves, we have witnessed a gradual convergence or heterogeneity in the film industries of many third-world developing countries and a mutual encroachment of cultural imperialism within these countries. This is precisely the potential impact of the cultural imperialism of the developed countries led by those Western countries such as the United States over the years. Like a chain reaction, such political legacies, which are more or less of colonialism, have extended to more countries and regions one after another. As a response strategy of "attacking to defend", some stronger developing countries have accordingly turned their attention to the weaker ones for continuity. The Nigerian film industry (as known as Nollywood) mentioned above, for example, was not only subjected to cultural invasion by its colonial power, Britain, but also to the pressures from India, also a former British colony. As Senayon Olaoluwa noted,

\begin{abstract}
"Nigeria's relations with India date back to the early twentieth century when about five million Indians were dispersed to different British colonies under the indentured labour system. As expected, Nigeria had its own share of an indentured labour population. .......Despite this long-standing record of economic relations, the emergence of India as an economic power has meant a general trend of imbalance in the trade relations with Nigeria's increasing import dependence on India [39]."
\end{abstract}

This situation contributed to the fact that India, also a former colony, became an accomplice to cultural imperialism -- if we regard the concept of cultural imperialism as all negative. However, as Olaoluwa claimed, at least in the instance of Nollywood, this is not entirely the case. The Nigerian film Indian Doctor (2008), one of the typical examples of Indian cultural imperialism germinating in the Nigerian film industry, did not degenerate into a slippery creation of a Westernism perspective like Black Panther (2018) [40], but used the contextual re-invention of Hinduism intexts to reflect on the mutation of Western modernity [39]. Such nonWestern cultural imperialism no longer implies any hegemonic overtones. According to the discussion of Dan Venning, this form of cultural imperialism actually 
emerged intercultural encounter between nations [10]. The fact is, as globalization deepens, the world has been increasingly becoming more and more multipolar, and although the cultural imperialism of the developed countries still lingers, its attribute as the intercultural encounter is gradually prevailing. Especially in those more underdeveloped countries, cultural imperialism brings not only erosion from the ideological aspect, but also introduces new technologies and new ideas. Taking Nigeria as an example again, some scholars argue that cultural imperialism from Anglophone and East Asian countries has contributed to the technological innovation of Nigeria's autochthonous film industry [18]. Consequently, many developing countries like Nigeria have made considerable advancements in the film industry thanks to the opportunities presented by cultural imperialism.

\section{CONCLUSION}

We discussed how cultural imperialism, driven by globalization, has a positive or negative impact on the film industry in non-Western countries. In the context of globalization, the centre of cultural imperialism has gradually turned to film and other industries. The transnational flow of culture with film as the carrier creates more opportunities for cultural imperialism. Western countries, especially the United States, export a lot of their culture to non-Western countries in large quantities through films, thus forming the Western media flow. The American film industry has taken an absolute leading position in the world. The film industry in many non-Western countries has been homogenized under the influence of cultural imperialism, and the production of films has gradually begun to follow the same model. However, at the same time, despite the inevitable influence of cultural imperialism from Western countries, there are still some countries, such as India and Nigeria, which combine the film mode from Western countries with their own cultural characteristics and realize the heterogeneity of local films. In this context, the impact of cultural imperialism on the film industry can not only be judged as positive or negative but should be discussed in combination with the actual situation of the country. It is hoped that this paper can help the media groups, cultural institutions, and Radio and Television Administration to make the film industry in China add more Chinese characteristics during production. At the same time, we also hope to have more research place to see how the film industry of non-Western countries can still highlight its own cultural characteristics under the influence of cultural imperialism, instead of blindly following the pattern set by the West and only driven by the economic factor.

\section{REFERENCES}

[1] T. Mirrlees, "CHAPTER 2 Capitalizing on Global Entertainment Media," in Global Entertainment Media: Between Cultural Imperialism and Cultural Globalization, Taylor \& Francis Group, 2013, pp. 59-103.

[2] N. Chomsky, American Power and the New Mandarins, Pantheon Books, The New Press, 1969.

[3] P. Brantlinger, "Review: Cultural Imperialism: A Critical Introduction. by John Tomlinson," The Journal of American History, vol. 79, no. 4, pp. 1694-1695, 1993.

[4] S. Narine, "Review: Essays on the Political Economy of Cultural Domination," International Journal, vol. 62, no. 1, pp. 206-209, 2007.

[5] J. Tomlinson, "Media Imperialism," in Cultural Imperialism: A Critical Introduction, London/New York, Continuum, 2002, pp. 34-67.

[6] M. B. Salwen, "Cultural imperialism: A media effects approach," Journal Critical Studies in Mass Communication, vol. 8, no. 1, pp. 29-38, 1991.

[7] A. Fătu-Tutoveanu, "Soviet Cultural Colonialism: Culture and Political Domination in the Late 1940sEarly 1950s Romania," TRAMES: A Journal of the Humanities \& Social Sciences, pp. 77-93, 1 March 2012.

[8] E. Akpabioa and K. Mustapha-Lambe, "Nollywood Films and the Cultural Imperialism Hypothesis," Perspectives on Global Development \& Technology, pp. 259-270, 1 September 2008.

[9] B. Sinha, "Empire films and the dissemination of Americanism in colonial India," South Asian History \& Culture, pp. 540-556, 1 October 2011.

[10] D. Venning, "Cultural Imperialism and Intercultural Encounter in Merchant Ivory's Shakespeare Wallah," Asian Theatre Journal, vol. 28, no. 1, pp. 149-167, 1 March 2011.

[11] J. Herlihy-Mera, After American Studies: Rething the Legacies of Transnational Exceptionalism, New York and London: Routledge Taylor \& Francis Group, 2018.

[12] T. L. McPhail, "Electronic colonialism: the future of international broadcasting and communication," Sage library of social research, vol. 126, p. 18, 1987.

[13] I. J. Ezema, "Globalisation, information revolution and cultural imperialism in Africa," Information, Society and Justice, vol. 3, no. 1, pp. 11-22, 2010.

[14] S. Phillipson, M. R. Raquel and J. C. Gube, "Chapter one: ENGLISH AND ITS ROLE IN HONG KONG 
CULTURAL IDENTITY," in Linguistic Diversity and Cultural Identity: A Global Perspective, T. Lê and Q. Lê, Eds., Nova Science Publishers, 2011.

[15] T. W. Tobin, "Cultural imperialism," Britannica, no. Lifestyles \& Social Issues, 26 May 2020.

[16] T. Flew and P. Iosifidis, "Populism, globalisation and social media," the International Communication Gazette, vol. 82, no. 1, pp. 7-25, 2020.

[17] Y. YunusaZ, "Globalization, ICTs, and the new imperialism: Perspectives on Africa in the Global Electronic Village," African Development, vol. 30, no. 1\&2, pp. 98-124, 2004.

[18] A. Mamman-Muhammad and S. U. Ogbu, "From Traditional to New Media: A Paradigm of Cultural Imperialism in Nigeria," Canadian Social Science, vol. 14, no. 7, pp. 97-103, 2018.

[19] Y. Lu, "The Relationship, Tension and Interaction between Cultural Imperialism and Contra-Flow in Contemporary Media Culture," Advances in Journalism and Communication, vol. 1, no. 4, pp. 50-53, 2013.

[20] E. A. Drysén, "A Critical Examination of Cultural Imperialism and its Impact on Global Communication Today," 2016. [Online]. Available: https://www.linkedin.com/pulse/criticalexamination-cultural-imperialism-its-impactglobal-drys\%C3\%A9n. [Accessed 1 December 2020].

[21] R. Acholonu, "Mass Media And Cultural Imperialism: The African Experience," European Scientific Journal, vol. 9, 2013.

[22] F. Fejes, "Media Imperialism: An Assessment," Media, Culture and Society, vol. 3, no. 3, pp. 281289, 1981.

[23] O. Boyd-Barrett, "Chapter 1: Redefining the Field," in Media Imperialism, SAGE Publications Ltd, 2016.

[24] R. Kroes, "The American on Western Europe: Americanization and Westernization in Transatlantic Perspective," Conference at the German Historical Institute, 25-27 March 1999.

[25] H. M. Stapell, "Beyond Cultural Imperialism: Rethinking Americanization, National Identity, and "Difference" in Post-Franco Spain," Journal of the Association for Spanish and Portuguese Historical Studies, vol. 41, no. 1, pp. 79-91, 2016.

[26] K. Robbins, "Review: The Rebirth of the West-The Americanization of the Democratic World, 19451958-Duigan, P; Gann, LH," English Historical Review, vol. 110, no. 435, pp. 260-261, Feb 1995.
[27] J. Tomlinson, Cultural Imperialism, London: Pinter Publishers, 1991.

[28] W. Maisuwong, "The Promotion of American Culture through Hollywood Movies to the World," International Journal of Engineering Research \& Technology (IJERT), vol. 1, no. 4, pp. 1-7, 2012.

[29] L. Srinivas, "The active audience: spectatorship, social relations and the experience of cinema in India," Media, Culture \& Society, vol. Volume 24, pp. 155-173, 2002.

[30] R. Mulligan, "Review: Globalization and American Popular Culture," The Journal of Popular Culture, vol. 41, no. 4, pp. 730-732, 2008.

[31] D. Crane, "Cultural globalization and the dominance of the American film industry: cultural policies, national film industries, and transnational film," International Journal of Cultural Policy, vol. 20, no. 4, pp. 365-382, 2014.

[32] G. Rodman, Mass Media and A Changing World: History, Industry, Controversy, New York: McGraw Hill, 2012.

[33] A. J. Scott, "Hollywood in the Era of Globalization: Will Hollywood continue to thrive in today's competitive global marketplace?," 29 November 2002. [Online]. Available: https://yaleglobal.yale.edu/content/hollywood-eraglobalization.

[34] D. Waldman, "Critical Theory and Film: Adorna and the "The Culture Industry" Revisited," New German Critique, vol. 12, pp. 39-60, 1977.

[35] M. Horkheimer and T. W. Adorno, Dialectic of Enlightenment, San Francisco: Stanford University Press, 2002.

[36] E. Aydemir, "Use of Hollywood as a Soft Power Tool in Foreign Policy Strategy of the United States of America," International Journal of Humanities and Social Science Invention, vol. 6, no. 11, pp. 7983, 2017.

[37] M. Gasher, "Cinema in the Age of Globalization," in Hollywood North: The Feature Film Industry in British Columbia, Vancouver, UBC Press, 2002, pp. 55-60.

[38] A. Hasan and F. A. Nika, "Glocalization: A study of Bollywood Movies," International Journal of Communication and Social Research, vol. 2, no. 2, pp. 55-60, 2014.

[39] S. Olaoluwa, "'We all come from Brahma': repetition and the anticipation of Indian cultural imperialism in Indian Doctor," Journal of African 
Cultural Studies, vol. 30, no. 8, pp. 279-292, 13 June 2017.

[40] R. A. Griffin and J. P. Rossing, "Black Panther in widescreen: cross-disciplinary perspectives on a pioneering, paradoxical film," Review of Communication, vol. 20, no. 3, pp. 203-219, 2020. 